\title{
The importance of protein profiling in the diagnosis and treatment of hematologic malignancies
}

\author{
Hematolojik malignitelerin tanı ve tedavisinde protein profillemenin önemi
}

\author{
Gülşah Şanlı-Mohamed1, Taylan Turan¹, Hüseyin Atakan Ekiz², Yusuf Baran³, \\ ${ }^{1}$ Department of Chemistry, Science Faculty, İzmir Institute of Technology, Urla, İzmir, Turkey \\ ${ }^{2}$ Department of Oncological Sciences, University of Utah, Salt Lake City, Utah, USA \\ ${ }^{3}$ Department of Molecular Biology and Genetics, Science Faculty, İzmir Institute of Technology, Urla, Izmir, Turkey
}

\begin{abstract}
Proteins are important targets in cancer research because malignancy is associated with defects in cell protein machinery. Protein profiling is an emerging independent subspecialty of proteomics that is rapidly expanding and providing unprecedented insight into biological events. Quantitative assessment of protein levels in hematologic malignancies seeks a comprehensive understanding of leukemiaassociated protein patterns for use in aiding diagnosis, follow-up treatment, and the prediction of clinical outcomes. Many recently developed high-throughput proteomic methods can be applied to protein profiling. Herein the importance of protein profiling, its exploitation in leukemia research, and its clinical usefulness in the treatment and diagnosis of various cancer types, and techniques for determining changes in protein profiling are reviewed. (Turk J Hematol 2011; 28: 1-14)

Key words: Hematologic malignancies, leukemia, proteomics, protein profiling
\end{abstract}

Received: November 24, 2010

Accepted: January 19, 2011

\section{Özet}

Malignitelerde proteinlerin hücresel mekanizmalarinda meydana gelen bozukluklardan dolayı, proteinler kanser araştırmaları için önemli hedeflerdir. Proteomiksin alt uzmanlık dalı olarak ortaya çıkan ve bağımsız bir alan olan protein profilleme biyolojik olaylara farklı bir bakıs açısı sağlamak amacıyla hızla gelişmektedir. Hematolojik malignitelerdeki protein düzeylerinin kantitatif olarak değerlendirilmesi, teşhise yardımcı olması, tedavinin izlenmesi ve klinik sonuçların tahmininde mükemmel bir yaklaşım olması nedeni ile lösemi ile ilgili protein modellerinin kapsamlı bir şekilde incelenmesini amaçlamaktadır. Son dönemlerde geliştirilen yüksek verimli yöntemler protein profillemede kullanılabilir. Bu makalede, protein profillemenin önemi, lösemi araştırmalarındaki rolü, çeşitli kanser tiplerinin tanısı ve tedavisi için klinik kullanımları ve protein profilindeki değişikliklerin belirlenmesinde kullanılan teknikler değerlendirilmiștir. (Turk J Hematol 2011; 28: 1-14)

Anahtar kelimeler: Hematolojik malignitiler, lösemi, proteomiks, protein profilleme 


\section{Introduction}

Proteins are abundant in all organisms and play key roles in most biological events as catalysts, transporters, and messengers. Thus, it is crucial to note that all research related to proteins increase our understanding of their levels, interactions, functions, modifications, regulations, and localization in cells $[1,2]$. Proteomics is a rapidly expanding discipline that aims to gain a comprehensive understanding of proteins. The term proteomics, which is a combination of protein and genomics, is used to define the large-scale analysis of a complete set of proteins - the chief components of cells that are responsible for the most significant metabolic pathways in cells or tissues [2-7]. The goal underlying proteomics is not only to identify all proteins in a cell, but also to identify the correlation between the genetic sequence and three-dimensional (3D) protein structure [2]. In other words, work in proteomics encompasses the investigation of proteinprotein interactions, the connection between the structure of proteins and their function, cellular processes and networks, and to improve protein separation and protein profiling techniques.

Protein profiling, an emerging independent subspecialty of proteomics, is poised to provide unprecedented insight into biological events. Quantitative evaluation of protein levels can be accomplished with protein profiling, which shows us unique expression patterns (diseased vs. healthy, treated vs. untreated, experimental vs. control) at the protein level when proteins from one cell type are compared with those of another cell type. The value of protein profiling is increasing daily and there are several reasons why it is of great importance, especially as a potential tool for the early diagnosis of leukemias and other diseases.

One such reason is that it provides a much better understanding of an organism, as it is not always possible or sufficient for scientists to clarify some metabolic pathways, including mechanisms of diseases, exclusively by studying the genome [2]. Additionally, there are some difficulties associated with accurately indentifying genes solely by dealing with genomic data [8]. To overcome this problem, data provided from genomic studies should be supported with data obtained from the study of proteins. Proteomics is often considered as the stage following genomics in the study of biological systems. Compared to genomics, proteomics is much more complicated, as the proteome differs from cell to cell, and under different conditions. This is because distinct genes are expressed in distinct cell types, and to identify even a basic group of proteins produced in a cell, one needs to have a comprehensive understanding of protein-related actions [2].

Until recently, such research was carried out using mRNA analysis via different methods, including microarray technology $[9,10]$ and serial analysis of gene expression (SAGE) [11]. On the other hand, recent studies demonstrate that mRNA analysis cannot be correlated directly with protein levels [12-17], as mRNA is not always translated into proteins [7]. Moreover, the quantity of protein formed for a given quantity of mRNA depends on both the gene that it is transcribed from and the current physiological state of the cell. As such, the level of transcription of a gene provides only a rough estimation of its extent of translation into a protein. Additionally, mRNA produced may go under rapid degradation that causes a reduction in translation, resulting in the production of less protein. In addition, some bodily fluids, such as serum and urine, have no source of mRNA under normal circumstances; therefore, proteomic technologies have emerged as an important addition to genomic studies [2].

Proteomics verifies the presence of a protein and provides a direct measure of the quantity present. An additional important reason that protein profiling is crucial is its power to analyze protein modifications. Although a particular cell may have a distinguishable set of proteins at various times or under various conditions, any particular protein may go through a wide range of alterations known as post-translational modifications, which will have critical effects on its function. Phosphorylation is an example of posttranslational modification. Structural proteins can undergo phosphorylation during cell signaling and result in the protein becoming a target for binding to or interacting with a distinct group of proteins that recognize the phosphorylated domain [18]. Ubiquitination is another post-translational type of modification. Ubiquitin is a small protein that can be affixed to certain protein substrates by means of enzymes known as E3 ubiquitin ligases [19]. Identifying which proteins are polyubiquitinated can be helpful in understanding how protein pathways are regulated. In addition to phosphorylation and ubiquitination, proteins can undergo additional modifications via methylation, acetylation, glycosyl- 
ation, oxidation, sulfation, hydroxylation, nitrosylation, amidation, etc.

These modifications can be assessed only at the protein level and modifications of many proteins expressed by a cell can be determined at the same time using such proteomic methods as phosphoproteomics and glycoproteomics [2]. In addition to modifications, there is no doubt that protein localization and interactions are of vital importance to their function. Mislocalization of a protein or any problem in signal transduction can turn normal cells into abnormal cells, which is a well-known paradigm in carcinogenesis. Protein profiling using proteomic methods can also be used to characterize these regulatory mechanisms. Another point that emphasizes the importance of protein profiling is that many proteins form complexes with other proteins and/or with nucleic acids, and exert their function in the presence of these molecules.

In summary, protein profiling provides a much better understanding of an organism, in terms of structure and function. Use of protein profiling in the study of multiple proteins, protein forms, and protein families - almost always by comparing 2 different states (diseased vs. healthy) - is expected to expand our understanding of molecular mechanisms. Elucidation of protein-protein interactions and signaling pathways, identification of biomarkers useful for drug development, serum profiling to identify patient populations that respond to various treatments, and eventually medical diagnostics in the near future can be implemented for hematological malignancies via proteomics.

\section{Exploitation of protein profiling in leukemia research}

Because leukemic cells lose regulation of growth controlling mechanisms, in most cases signaling pathways involving numerous proteins are altered, as mentioned before. When this is taken into account, not surprisingly, expression patterns of growth-inducing and growth-suppressing genes change with malignant transformation [20,21]. Therefore, monitoring these changes is of great importance for understanding carcinogenesis, identifying diagnostic markers, and developing new therapeutics for leukemia. The most widely used methods for this involve examination of differential gene expression in leukemic cells by assessing the mRNA levels in the given cells. Several successful studies reported the feasibil- ity of this approach [22-25]. On the other hand, this methodology comes from a reductionist point of view, as it neglects the dynamic nature of protein translation and further modifications that take place beyond transcription. As such, an approach involving direct proteomic methods might be a better choice for obtaining more accurate insight into what is happening at the cellular level in leukemic cells.

Although the initial changes that occur during the development of hematologic malignancies appear as little sparks igniting a larger fire, the majority of leukemias manifest with profound alterations in protein profiles. In some types of leukemia, growthsuppressive genes undergo mutations and nullify protein synthesis completely, whereas in other types aberrant proteins arise due to chromosomal rearrangement, which is not usually seen in healthy cells. Those alterations are readily detectable with current proteomic methods. What follows are examples of proteins whose cellular presence changes most significantly with malignant transformation, and from this perspective the feasibility of protein profiling for the diagnosis and therapy of hematological malignancies becomes evident.

P53 has been perhaps the most famous protein for decades because of its essential role in cell cycle regulation, apoptosis and senescence. It is a transcription factor that responds to stressful conditions by inducing cell cycle arrest and apoptosis. Not surprisingly, it was reported that p53 is deleted or mutated in the majority of cancers. Experiments involving p53 knockout mice have shown that the occurrence of tumors increases with the loss of p53 function [26,27]. In some cases inactivation of p53 involves small changes such as point mutations [28$30]$. On the other hand, numerous other leukemias manifest with more global changes in the p53 protein structure. The protein can also be tagged for proteolytic degradation by interacting with another protein, MDM2 [31], or without the need of a degradation protein can be inactivated by exporting back to cytoplasm, inhibiting its DNA-binding functions [32]. Major structural alterations aside, p53 can be inactivated by binding to other proteins [32] and by chemical modifications, such as phosphorylation and acetylation [33,34], and we know that these alterations are traceable using proteomic methods. Furthermore, signaling networks of p53 and downstream targets can also be examined proteomically 
to gain more comprehensive insight into carcinogenesis.

While p53 is a protein commonly altered in numerous cancers, there are some proteins that appear to be signature molecules for particular cancer types. Such proteins are important for diagnostic purposes and might be used in cancer therapeutics as highly selective targets. Chronic myeloid leukemia (CML) is a wonderful example. CML is characterized by accumulation of immature blasts of myeloid origin in the bloodstream and bone marrow. The main driving force of leukemogenesis in CML is reciprocal translocation between chromosomes 9 and 22, which produces a fusion protein (BCR-ABL) having constitutive tyrosine kinase activity, and, in turn, induces cell growth [35]. BCR-ABL is one of the most prominent proteins in leukemic cells and its overexpression is linked to chemotherapeutic drug resistance [36]. With the increased knowledge about this fusion protein, highly specific drugs were developed and considerable cytogenetic responses were delineated [37-39]. In the light of these advancements in leukemia therapy, it is obvious that identification of proteins responsible for malignant transformation is particularly important for the development of efficient drugs. The current literature has provided detailed insight into the pathogenesis of CML, but there are numerous other cancer types whose pathophysiology remains to be elucidated. At this point, the need for the utilization of proteomic methods rather than genomic methodologies is clear, as it provides a deeper understanding of the features of leukemic cells.

The literature sheds light on the specifics of different types of leukemias, as the mechanism of CML has been described. For instance, acute lymphoblastic leukemia (ALL) cells were reported to express unique tyrosine kinases that originate from Abl kinase, which are thought to be important for malignancy [40]. In some ALL patients, chromosomal translocations create ABL1/NUP214 or P2RY8/ CRLF2 fusion proteins with oncogenic activity [41,42]. T-cell ALL cells undergo site-specific genetic alterations in the TAL1 gene due to problematic activity of the enzyme recombinase, and as a result, a truncated protein with oncogenic activity is produced [43]. Translocations involving this region were also shown to be important for ALL leukemogenesis [44-46]. Similarly, KRAS2 protein with a genetic insertion was shown to play a role in malignant transformation by activating the RAS-activated signaling pathway in acute myeloid leukemia (AML) cells [47]. Additionally, some cases of AML were caused by alterations in CEBPA and NPM proteins via mutations $[48,49]$.

Proteins with role in the development of hematological malignancies are not confined to those already mentioned. There are many others identified as responsible for malignant transformation, and without any doubt there are many other proteins whose mysteries remain unsolved. Moreover, understanding the complex signaling networks amongst the proteins is no less important than identifying the proteins themselves; therefore, it is clear that proteomic techniques and protein profiling are especially valuable for obtaining a deeper understanding of malignant transformation, improved diagnostics, and more accurate prognostic predictions, and for the development of effective therapeutic options. Genomics has provided a considerable body of useful information on the alterations in cancer cells by identifying the genes responsible for tumor suppression and growth, but as long as the complex interactions of proteins and the dynamic nature of protein synthesis are overlooked, genomics will be unable to establish a complete understanding of malignancy.

Because the information stored in genes is reflected in the phenotype by proteins, assessment of proteins in the cell at a given time would provide accurate and detailed insight into the specifics of the cell type being investigated. Despite advancements in leukemia therapy, we remain baffled by the complexity of cancer cells and their adaptation to current therapies; hence, we are still unable to provide an effective solution. Nonetheless, as more knowledge about the specifics of leukemic cells is obtained, such as oncogenic proteins, more effective therapies will be developed. The development of tyrosine kinase inhibitors is a wonderful example. Nowadays, survival time in CML patients is greatly prolonged due to the availability of these inhibitors [50,51]. Hopefully, as the utilization of proteomic techniques in leukemia research increases, promising new targets and treatment opportunities will emerge in a near future. The major important proteins in different types of leukemias are summarized in Table 1. 


\section{Protein profiling: clinical implications}

Investigating protein profiles and understanding the dynamic alterations of cellular proteins are of great importance for diagnostic and therapeutic purposes in clinical settings. This is because most diseases, cancers in particular, are reflected as driven by protein alterations in cells. As such, proteomic methods enhance our understanding of the characteristics of various cancers via discovering new biomarkers, making it possible to discriminate healthy and malignant cells more accurately, development of novel therapeutics that target altered protein signaling pathways, and assessment of what changes occur at the protein level in cells in response to treatment with drugs, leading to the evaluation of therapeutic efficacy. In fact, several studies reported that protein signatures were potent discriminators of diseased and healthy cells. Such an approach used with serum proteins discriminated CML cells from healthy cells. Differences in protein levels were identified using matrix-assisted laser desorption/ionization time of flight (MALDITOF) analysis and spectrum comparisons showed that there were 31 differentially expressed proteins involved in cell growth, survival, and programmed cell death [100]. Barnidge et al. analyzed CLL patient samples to characterize CLL B-cell protein expression at the quantitative and qualitative level using two-dimensional liquid-chromatography cou- pled to MALDI tandem mass spectrometry (2D-LCMS/MS) [101].

The power of proteomic techniques is not only limited to distinguishing the diseased state from the healthy state, but it also helps to resolve tumor subtypes. The latter is especially important for the prediction the prognostic features of cancer and for determining the therapeutic strategy to be adopted. It was previously reported that pathologic changes in hematological malignancies are correlated with the protein profiles of cells; 247 different protein spots were identified between the HL-60 (acute promyelocytic leukemia), MEC1 (B-cell chronic lymphocytic leukemia), CCRF-CEM (T-cell acute lymphoblastic leukemia), and Raji (B-cell Burkitt's lymphoma) cells [102]. In another study, differentially expressed serum proteins were identified in non-Hodgkin's lymphoma (NHL) patients before treatment, lymphnoditis patients, and healthy adults using surface-enhanced laser desorption/ionization time of flight mass spectrometry (SELDI-TOF MS) [103]. Significant differences were observed in different phases of NHL. The study showed that levels of 3 main proteins could be used for the early and differential diagnosis of NHL [103]. Differences in protein levels can be used as a diagnostic marker to characterize tumors.

In addition to its contribution to our knowledge of tumor subtypes, proteomics combined with

Table 1. Major important proteins in hematological malignancies

\begin{tabular}{lll}
\hline & Type of Hematological Malignancy & Major Important Proteins \\
\hline Leukemias & Acute lymphoblastic leukemia (ALL) & P53 (30, 52, 53), TEL/AML1 (54), E2A/PBX (PBX1) (55), \\
& & BCR/ABL (56), MLL/AF4 (57), IGH/MYC (58), \\
& & TCR/RBTN2 (59), TdT (60,61), ABL1/NUP214 (41), \\
& P2RY8/CRLF2 (42) and Tal1 (43) proteins
\end{tabular}


other gene expression analyses can be used to characterize the tumor microenvironment, which has profound effects on tumor progression [104,105]. Identifying the characteristics of cancer subtypes leads to a better understanding of chemotherapeutic resistance as well. Use of proteomic methods to identify alterations at the protein level that confer resistance to cancer cells and nullify current chemotherapeutic options is therefore of great interest for use in the development of novel interventions with increased efficacy against resistance. Twodimensional differential gel electrophoresis (2-DE) coupled with mass spectrometry analysis between imatinib-sensitive and resistant KCL22 CML cells showed that there were 27 over-expressed and 24 under-expressed proteins involved in proliferation and apoptosis. Such data may open new ways of determining novel targets for the treatment of drugresistant leukemias [106]. However when mRNA expression levels in these proteins were examined, similar patterns were not observed, indicating that post-translational control is also very important for different protein profiles. This observation highlights the importance of proteomics, in terms of illuminating what accounts for the difference between sensitivity and resistance to chemotherapy in cells. As it helps differentiate resistant subtypes, proteomics techniques can be used for predicting chemotherapeutic susceptibility [107].

The protein content of cancer cells is also subject to changes in response to treatment with drugs and radiation. Therefore, protein profiling can be utilized to compare treated cells and untreated counterparts to better understand the therapeutic mechanisms of action and possible points of intervention for obtaining better responses to current therapies. Protein profiles are not only important for delineating drug mechanisms, but also for monitoring minimal residual disease (MRD) in cancer patients treated with various forms of anti-cancer agents. It was reported that a panel of antibodies could be used in microarrays to trace disease-specific proteins in CLL patient samples that were previously treated with rituximab [108]. A broader analysis of several different CLL-specific antigens would be more accurate, in terms of identifying MRD, than previously adopted assessment of CD20 expression, which cannot be measured accurately during the course of rituximab treatment. In addition to the current advanced techniques for the assessment of cellular proteins, this area is still open to development. For instance, 2-nitrobenzenesulfenyl chloride (NBS) isotope labeling coupled with 2-DE and mass spectrometry was shown to yield more reliable results than the conventional methods of analyzing protein levels [109].

\section{Techniques for determining changes in protein profiles}

Proteins are important targets for drug discovery and are therefore utilized in cancer research because there are defects in the protein machinery of cells undergoing malignant transformation. Identification of protein profiles is clinically promising in the development of potential new drugs to eradicate various malignancies, including, but not limited to, those of hematologic origin. Changes in protein profiles provide a wide variety of critical data regarding various cancers. By examining these alterations proteins that have a profound impact on the progression of diseases can be identified, making the development of individually tailored drugs possible [1]. Because of its importance, recent technologic advances have opened a new era for analyzing changes in protein profiles. To date, many of the high-throughput protein identification and characterization methods developed for proteomics have been applied to protein profiling. Among them, the most widely and efficiently used ones are mass spectrometry, sometimes in combination with different chromatographic methods [110-115], protein microarray [115-118], and high-performance liquid chromatography laser-induced fluorescence (HPLC-LIF) [119, 120].

\section{Mass spectrometry}

Mass spectrometry is a technique used for the analysis of complex protein samples in order to detect a given set of proteins. Its principle depends primarily on separating ionized molecules according to their mass to charge ratios [2]. Matrix-assisted laser desorption/ionization time of flight mass spectrometry (MALDI-TOF MS), liquid-chromatography coupled to MALDI tandem mass spectrometry (LCMS/MS), and surface-enhanced laser desorption/ ionization mass spectrometry (SELDI MS) are of great importance to applying mass spectrometry to clinical biomedicine. For the application of mass spectrometry the first step (sample preparation) is the resolution of proteins in complex mixtures obtained from whole organisms, cell lines, tissues, or bodily fluids. The most widely used method for resolution and visualization of proteins for mass 
spectrometry is 2-DE. Chromatographic approaches could also be adopted for better separation of proteins of interest.

Protein electrophoresis has remained the most effective way to resolve a complex mixture of proteins since 1970s. For the case of protein profiling, 2 -DE is more applicable because complex protein mixtures such as crude cell lysates can be resolved better, not only according to molecular mass but also to isoelectric properties of proteins [121]. Two distinct characteristics of proteins facilitate resolution of protein mixtures by their net charge in the first dimension and by their molecular mass in the second dimension. In protein profiling, protein expressions of 2 given samples (diseased vs. healthy for instance) can be compared, both qualitatively and quantitatively. Differences in protein quantities are indicated by the appearance or disappearance of spots in 2-DE gel and quantitative information about protein levels can be provided by the assessment of the spot intensity in the gel. Resolution and visualization of up to ten thousand proteins in a single sample via 2-DE is a powerful approach for the analysis of samples from a variety of sources, including cell lines and body fluids. Although there are some drawbacks to this methodology, such as poor reproducibility, labor intensiveness, a slow and tedious procedure that can't be easily automated, and dependence of the results on the expertise of the analyst, it is still an essential component of proteomics for protein profiling.

\section{Protein microarray}

Protein microarray is a technique used in most biomedical applications for determining the presence and quantity of proteins in a biological system. It has great potential to increase the throughput of proteomic research. Although analytical microarrays, functional microarrays, and reverse phase microarrays are 3 types of protein microarrays currently used for studying the biochemical activity of proteins, analytical microarrays are typically used to profile a complex mixture of proteins, in terms of measuring binding affinities, specificities, and protein expression levels of the proteins in the mixture [122]. It is a very powerful technique that can be used to monitor differential expression of proteins for clinical diagnosis, prediction of prognosis, and identification of targets for therapy. In general, first a library of antibodies, aptamers, or affibodies is arrayed on a glass microscope slide, and then the prepared array is probed with the protein solution. To date, protein profiling using analytical microarray has been implemented successfully for the assessment of responses to environmental stress and differences between healthy and diseased tissues [123]. When positive and negative controls are used carefully there aren't many drawbacks to this methodology, yet microarray studies are limited due to their cost.

\section{High-performance liquid chromatography laser- induced fluorescence}

High-performance liquid chromatography laserinduced fluorescence (HPLC-LIF) is another technique used for the detection of differentially expressed proteins by simultaneously recording spectra and chromatograms of physiological samples in a short time [124]. Though to the best of our knowledge this technique has not been utilized in hematologic malignancies, it is useful in the early diagnosis of certain types of cancer, including cervical cancer and oral cancer [119,120,124-126].

The above-mentioned technique is composed of the combination of laser-induced fluorescence, an ultra-sensitive optical method, and high-performance liquid chromatography. The principle of HPLC-LIF is based on recording the chromatographic peaks and corresponding fluorescence spectra at the same time. This makes it possible to differentiate diseased and healthy, treated and untreated, and/or experimental and control sample protein profiles, even in femto/subfemtomole quantities [126]. Even though use of the technique is restricted, as compared to the others, there is no doubt that it is a very powerful and sensitive method [125].

\section{Drawbacks of protein profiling}

Although analysis of important proteins in biological systems is important, there are several drawbacks of protein profiling due to techniques like mass spectrometry in combination with separation tools such as 2-DE [114,127,128]. First of all, these techniques are labor intensive and time consuming for the analysis of proteins. Improved robotics may increase the frequency with which these techniques are utilized, as well as their efficiency. Secondly, 2-DE lacks the sensitivity to detect low quantities of proteins and therefore requires a significant quantity of biological material [129,130]. Additionally, most of the time high-quantity proteins can mask low-quantity proteins that may be important biomarkers in hematologic malignancies. To overcome this type of drawback immunodepletion and multidimensional chromatography may be a reasonable solution [131]. 
Through sample purification, low-quantity proteins may be lost due to interactions with other highquantity proteins; therefore, all steps of purification must be analyzed. Sample collection, processing, and, ultimately, sample measurement are also very crucial for the utilization of protein profiling in many clinical settings. Consistency, use of strict protocols, running replicates for each sample, and increasing the sample count can be a general solution to eliminating such drawbacks. Other obstacles to the use of techniques in protein profiling can be ascribed to poor resolution of spots after 2-DE, non-identification of mass spectrometry peaks, and the limitations of databanks for unknown proteins. Protein microarray [132,133] and HPLC-LIF, alternative techniques for protein profiling, have fewer drawbacks when

Table 2. Advantages and disadvantages of protein profiling techniques

\begin{tabular}{|c|c|c|}
\hline Different Techniques & Advantages & Disadvantages \\
\hline \multirow[t]{7}{*}{ 2D Gel Electrophoresis } & - High resolution & - Slow \\
\hline & - Quantitative & - Lacks automation \\
\hline & - Qualitative & - Poor reproducibility \\
\hline & - Sample variety (cell lines and body fluids) & - Labor intensive \\
\hline & - Many protein analyses in a single run & - Tedious procedure \\
\hline & & - Requires a significant quantity of sample \\
\hline & & - Lacks sensitivity for low-quantity proteins \\
\hline \multirow[t]{4}{*}{ SELDI-TOF MS } & - Fast & - Limited to low-MW proteins \\
\hline & - Good for diagnostic patterns of disease & - Preferably used in serum samples \\
\hline & - Limited resolution & \\
\hline & - Accuracy of quantification is restricted & \\
\hline \multirow[t]{6}{*}{ MALDI-TOF MS } & • Fast & - Limited databank information \\
\hline & - Buffer/salt tolerance & - Limited resolution of peaks \\
\hline & - Off-line & - Low dynamic range of detection \\
\hline & - Mass accuracy & \\
\hline & - Mixture of samples okay & \\
\hline & - Small and large polypeptide analysis & \\
\hline \multirow[t]{6}{*}{ Protein Microarrays } & - Highly informative & - Difficult to achieve general binding conditions \\
\hline & - Qualitative & - Time consuming \\
\hline & - Quantitative & - Costly procedure \\
\hline & - Powerful technique & \\
\hline & - Target specific & \\
\hline & - Successful in improving sensitivity and specificity & \\
\hline \multirow[t]{2}{*}{ LC-MS/MS } & - Straightforward protein identification & - Slow, but can be automated \\
\hline & - High sensitivity & - Slow, but can be automated it is used two \\
\hline & - Good resolution & - Analysis of a limited number of samples \\
\hline & - Characterizes post-translational modifications & \\
\hline \multirow[t]{5}{*}{ HPLC-LIF } & • Powerful & - Low reproducibility \\
\hline & - Time efficient & \\
\hline & - Sensitive & \\
\hline & - Fast & \\
\hline & - High detection capacity & \\
\hline
\end{tabular}

- Good for use in early diagnosis 
compared with the aforementioned methods, but they are preferred less because they require welltrained experts. The advantages and disadvantages of the techniques used for protein profiling are summarized in Table 2.

\section{Conclusion and future perspectives}

Discovery of leukemia-associated protein patterns is an excellent tool for aiding diagnosis, follow-up treatment, and predicting clinical outcomes. In the future, the determination of individual protein profiles in hematological malignancies and other types of cancers, together with the investigation of genomic profiles is expected to contribute to the development of tailor-made treatments. Protein profiling strategies that identify the pattern of changes in protein levels are therefore not only promising for hematological diseases, but also for other types of cancers, and may lead to the development of novel tools and interventions of unprecedented diagnostic and/or prognostic value.

\section{Conflict of interest statement}

None of the authors of this paper has a conflict of interest, including specific financial interests, relationships, and/or affiliations relevant to the subject matter or materials included.

\section{Acknowledgment}

This study was supported by the Turkish Academy of Sciences, Outstanding Young Investigator Programme.

\section{References}

1. Twyman RM. Principles of Proteomics. New York: Academic Press, 2004.

2. Graves PR, Haystead TAJ. Molecular Biologist's Guide to Proteomics. Microbiology and Molecular Biology Reviews 2002;66:39-63. [CrossRef]

3. Wilkins MR, Sanchez JC, Gooley AA, Appel RD, Humphery-Smith I, Hochstrasser DF, Williams KL. Progress with proteome projects: why all proteins expressed by a genome should be identified and how to do it. Biotechnol. Genet. Eng. Rev. 1996;13:19-50.

4. Pandey A, Mann M. Proteomics to study genes and genomes. Nature 2000;405:837-46. [CrossRef]

5. James P. Protein identification in the post-genome era: the rapid rise of proteomics. Quarterly Reviews of Biophysics 1997;30:279-331. [CrossRef]

6. Wilkins MR, Pasquali C, Appel RD, Ou K, Golaz O, Sanchez JC, Yan JX, Gooley AA, Hughes G, Smith IH, Williams KL, Hochstrasser DF. From Proteins to Proteomes: Large Scale Protein Identification by Two-
Dimensional Electrophoresis and Amino Acid Analysis. Nature Biotechnology 1996;14:61-5. [CrossRef]

7. Lane CS. Mass spectrometry-based proteomics in the life sciences. Cellular and Molecular Life Sciences. 2005;62:848-69. [CrossRef]

8. Eisenberg D, Marcotte EM, Xenarios I, Yeates TO. Protein function in the post-genomic era. Nature 2000;405:823-6. [CrossRef]

9. Schena M, Shalon D, Davis RW, Brown PO. Quantitative monitoring of gene expression patterns with a complementary DNA microarray. Science 1995;270:467-70. [CrossRef]

10. Shalon D, Smith SJ, Brown PO. A DNA microarray system for analyzing complex DNA samples using twocolor fluorescent probe hybridization. Genome Research. 1996;6:639-45. [CrossRef]

11. Velculescu VE, Zhang L, Vogelstein B, Kinzler KW. Serial analysis of gene expression. Science 1995;270:484-7. [CrossRef]

12. Abbott A. A post-genomic challenge: learning to read patterns of protein synthesis. Nature 1999;402:715-20.

13. Anderson L, Seilhamer J. A comparison of selected mRNA and protein abundances in human liver. Electrophoresis 1997;18:533-7. [CrossRef]

14. Gygi SP, Rochon Y, Franza BR, Aebersold R. Correlation between protein and mRNA abundance in yeast. Molecular and Cellular Biology 1999;19:1720-30.

15. Ideker T, Thorsson V, Ranish JA, Christmas R, Buhler J, Eng JK, Bumgarner R, Goodlett DR, Aebersold R, Hood L. Integrated genomic and proteomic analyses of a systematically perturbed metabolic network. Science 2001;292:929-34. [CrossRef]

16. Rogers S, Girolami M, Kolch W, Waters KM, Liu T, Thrall $\mathrm{B}$, Wiley HS. Investigating the correspondence between transcriptomic and proteomic expression profiles using coupled cluster models. Bioinformatics 2008;24:2894-900. [CrossRef]

17. Dhingraa V, Gupta M, Andacht T, Fu ZF. New frontiers in proteomics research: A perspective. International Journal of Pharmaceutics 2005;299:1-18. [CrossRef]

18. Hunter T. Protein kinases and phosphatases: the yin and yang of protein phosphorylation and signaling. Cell 1995;80:225-36.

19. Glickman MH, Ciechanovr A. The ubiquitin-proteasome proteolytic pathway; destruction for the sake of construction. Physiological Reviews 2002;82:373-428.

20. Eberhart CE, Coffey RJ, Radhika A, Giardiello FM, Ferrenbach S, DuBois RN. Up-regulation of cyclooxygenase 2 gene expression in human colorectal adenomas and adenocarcinomas. Gastroenterology 1994; 107:1183-8.

21. Bártek J, Bártková J, Vojtěsek B, Stasková Z, Lukás J, Rejthar A, Kovarík J, Midgley CA, Gannon JV, Lane DP. Aberrant expression of the p53 oncoprotein is a common feature of a wide spectrum of human malignancies. Oncogene 1991;6:1699-703.

22. Lin KY, Lu D, Hung CF, Peng S, Huang L, Jie C, Murillo F, Rowley J, Tsai YC, He L, Kim DJ, Jaffee E, Pardoll D, 
Wu TC. Ectopic expression of vascular cell adhesion molecule-1 as a new mechanism for tumor immune evasion. Cancer Research 2007;67:1832-41. [CrossRef]

23. Ye P, Mariniello B, Mantero F, Shibata H, Rainey WE. G-protein-coupled receptors in aldosterone-producing adenomas: a potential cause of hyperaldosteronism. Journal of Endocrinology 2007;195:39-48. [CrossRef]

24. Gashaw I, Grümmer R, Klein-Hitpass L, Dushaj O, Bergmann M, Brehm R, Grobholz R, Kliesch S, Neuvians TP, Schmid KW, von Ostau C, Winterhager E. Gene signatures of testicular seminoma with emphasis on expression of ets variant gene 4. Cellular and Molecular Life Sciences 2005;62:2359-68. [CrossRef]

25. Spira A, Beane JE, Shah V, Steiling K, Liu G, Schembri F, Gilman S, Dumas YM, Calner P, Sebastiani P, Sridhar S, Beamis J, Lamb C, Anderson T, Gerry N, Keane J, Lenburg ME, Brody JS. Airway epithelial gene expression in the diagnostic evaluation of smokers with suspect lung cancer. Nature Medicine 2007;13:361-6. [CrossRef]

26. Schmitt CA, Fridman JS, Yang M, Baranov E, Hoffman RM, Lowe SW. Dissecting p53 tumor suppressor functions in vivo. Cancer Cell 2002;1:289-98. [CrossRef]

27. Sørensen BS, Gebhardt MC, Kloen P, McIntyre J, Aguilar F, Cerutti P, Børresen AL. Screening for TP53 mutations in osteosarcomas using constant denaturant gel electrophoresis (CDGE). Human Mutation 1993;2:274-85. [CrossRef]

28. Mathupala SP, Heese C, Pedersen PL. Glucose catabolism in cancer cells. The type II hexokinase promoter contains functionally active response elements for the tumor suppressor p53. The Journal of biological chemistry 1997;272:22776-80. [CrossRef]

29. Hsu IC, Metcalf RA, Sun T, Welsh JA, Wang NJ, Harris CC. Mutational hotspot in the p53 gene in human hepatocellular carcinomas. Nature 1991;350:427-8. [CrossRef]

30. Kawamura M, Kikuchi A, Kobayashi S, Hanada R, Yamamoto K, Horibe K, Shikano T, Ueda K, Hayashi K, Sekiya $\mathrm{T}$, et al. Mutations of the p53 and ras genes in childhood $\mathrm{t}(1 ; 19)$-acute lymphoblastic leukemia. Blood 1995;85:2546-52.

31. Fuchs SY, Adler V, Buschmann T, Yin Z, Wu X, Jones SN, Ronai Z. JNK targets p53 ubiquitination and degradation in nonstressed cells. Genes \& development 1998;12:2658-63. [CrossRef]

32. Foo RS, Nam YJ, Ostreicher MJ, Metzl MD, Whelan RS, Peng CF, Ashton AW, Fu W, Mani K, Chin SF, Provenzano E, Ellis I, Figg N, Pinder S, Bennett MR, Caldas C, Kitsis RN. Regulation of p53 tetramerization and nuclear export by ARC. Proceedings of the National Academy of Sciences of the United States of America 2007;104:20826-31. [CrossRef]

33. Shieh SY, Ikeda M, Taya Y, Prives C. DNA damageinduced phosphorylation of p53 alleviates inhibition by MDM2. Cell 1997;91:325-34.

34. Luo J, Su F, Chen D, Shiloh A, Gu W. Deacetylation of p53 modulates its effect on cell growth and apoptosis. Nature 2000;408:377-81. [CrossRef]

35. Skorski T, Nieborowska-Skorska M, Nicolaides NC, Szczylik C, Iversen P, Iozzo RV, Zon G, Calabretta B.
Suppression of Philadelphial leukemia cell growth in mice by BCR-ABL antisense oligodeoxynucleotide. Proceedings of the National Academy of Sciences of the United States of America 1994;91:4504-8. [CrossRef]

36. Baran Y, Ural AU, Gunduz U. Mechanisms of cellular resistance to imatinib in human chronic myeloid leukemia cells. Hematology 2007;12:497-503. [CrossRef]

37. Saglio G, Kim DW, Issaragrisil S, le Coutre P, Etienne G, Lobo C, Pasquini R, Clark RE, Hochhaus A, Hughes TP, Gallagher N, Hoenekopp A, Dong M, Haque A, Larson RA, Kantarjian HM; ENESTnd Investigators. Nilotinib versus imatinib for newly diagnosed chronic myeloid leukemia. The New England Journal of Medicine 2010;362:2251-9.

38. Kantarjian H, Shah NP, Hochhaus A, Cortes J, Shah S, Ayala M, Moiraghi B, Shen Z, Mayer J, Pasquini R, Nakamae H, Huguet F, Boqué C, Chuah C, Bleickardt E, Bradley-Garelik MB, Zhu C, Szatrowski T, Shapiro D, Baccarani M. Dasatinib versus imatinib in newly diagnosed chronic-phase chronic myeloid leukemia. The New England Journal of Medicine 2010;362:2260-70. [CrossRef]

39. Nagai T, Takeuchi J, Dobashi N, Kanakura Y, Taniguchi S, Ezaki K, Nakaseko C, Hiraoka A, Okada M, Miyazaki Y, Motoji T, Higashihara M, Tsukamoto N, Kiyoi $\mathrm{H}$, Nakao S, Shinagawa K, Ohno R, Naoe T, Ohnishi K, Usui N. Imatinib for newly diagnosed chronic-phase chronic myeloid leukemia: results of a prospective study in Japan. International journal of hematology 2010;92:111-7. [CrossRef]

40. Clark SS, McLaughlin J, Crist WM, Champlin R, Witte ON. Unique forms of the abl tyrosine kinase distinguish Ph1-positive CML from Ph1-positive ALL. Science 1987;235(4784):85-8. [CrossRef]

41. Graux C, Cools J, Melotte C, Quentmeier H, Ferrando A, Levine R, Vermeesch JR, Stul M, Dutta B, Boeckx N, Bosly A, Heimann P, Uyttebroeck A, Mentens N, Somers R, MacLeod RA, Drexler HG, Look AT, Gilliland DG, Michaux L, Vandenberghe P, Wlodarska I, Marynen P, Hagemeijer A. Fusion of NUP214 to ABL1 on amplified episomes in T-cell acute lymphoblastic leukemia. Nature genetics 2004;36:1084-9. [CrossRef]

42. Mullighan CG, Goorha S, Radtke I, Miller CB, Smith EC, Dalton JD, Girtman K, Mathew S, Ma J, Pounds SB, Su X, Pui CH, Relling MV, Evans WE, Shurtleff SA, Downing JR. Genome-wide analysis of genetic alterations in acute lymphoblastic leukaemia. Nature 2007;446:758-64. [CrossRef]

43. Brown L, Cheng JT, Chen Q, Siciliano MJ, Crist W, Buchanan G, Baer R. Site-specific recombination of the tal-1 gene is a common occurrence in human $\mathrm{T}$ cell leukemia. The EMBO journal 1990;9:3343-51.

44. Finger LR, Kagan J, Christopher G, Kurtzberg J, Hershfield MS, Nowell PC, Croce CM. Involvement of the TCL5 gene on human chromosome 1 in T-cell leukemia and melanoma. Proceedings of the National Academy of Sciences of the United States of America 1989;86:5039-43. [CrossRef]

45. Bernard O, Barin C, Charrin C, Mahul DM, Berger R. Characterization of translocation $\mathrm{t}(1 ; 14)(\mathrm{p} 32 ; \mathrm{q} 11)$ in a $\mathrm{T}$ and in a B acute leukemia. Leukemia 1993;7:1509-13. 
46. Curry JD, Smith MT. Measurement of SIL-TAL1 fusion gene transcripts associated with human T-cell lymphocytic leukemia by real-time reverse transcriptase-PCR. Leukemia research 2003;27:575-82. [CrossRef]

47. Bollag G, Adler F, elMasry N, McCabe PC, Conner E Jr, Thompson P, McCormick F, Shannon K. Biochemical characterization of a novel KRAS insertion mutation from a human leukemia. The Journal of biological chemistry 1996;271:32491-4. [CrossRef]

48. Smith ML, Cavenagh JD, Lister TA, Fitzgibbon J. Mutation of CEBPA in familial acute myeloid leukemia. The New England journal of medicine 2004;351:2403-7. [CrossRef]

49. Falini B, Mecucci C, Tiacci E, Alcalay M, Rosati R, Pasqualucci L, La Starza R, Diverio D, Colombo E, Santucci A, Bigerna B, Pacini R, Pucciarini A, Liso A, Vignetti M, Fazi P, Meani N, Pettirossi V, Saglio G, Mandelli F, Lo-Coco F, Pelicci PG, Martelli MF; GIMEMA Acute Leukemia Working Party. Cytoplasmic nucleophosmin in acute myelogenous leukemia with a normal karyotype. The New England journal of medicine 2005;352:254-66. [CrossRef]

50. Golemovic M, Verstovsek S, Giles F, Cortes J, Manshouri T, Manley PW, Mestan J, Dugan M, Alland L, Griffin JD, Arlinghaus RB, Sun T, Kantarjian H, Beran M. AMN107, a novel aminopyrimidine inhibitor of Bcr-Abl, has in vitro activity against imatinib-resistant chronic myeloid leukemia. Clinical Cancer Research 2005;11:4941-7. [CrossRef]

51. Artinyan A, Kim J, Soriano P, Chow W, Bhatia S, Ellenhorn JD. Metastatic gastrointestinal stromal tumors in the era of imatinib: improved survival and elimination of socioeconomic survival disparities. Cancer epidemiology, biomarkers \& prevention 2008;17:2194-201. [CrossRef]

52. Lanza C, Gaidano G, Cimino G, Lo Coco F, Basso G, Sainati L, Pastore C, Nomdedeu J, Volpe G, Parvis G, et al. p53 gene inactivation in acute lymphoblastic leukemia of B cell lineage associates with chromosomal breakpoints at 11q23 and 8q24. Leukemia 1995;9:955-9.

53. Yeargin J, Cheng J, Yu AL, Gjerset R, Bogart M, Haas M. P53 Mutation in Acute T Cell Lymphoblastic Leukemia Is of Somatic Origin and Is Stable during Establishment of T Cell Acute Lymphoblastic Leukemia Cell Lines. The Journal of Clinical Investigation 1993;91:2111-7. [CrossRef]

54. Stams WAG, Boer MLD, Beverloo HB, Meijerink JPP, Wering ERV, Schaub GEJ, Pieters R. Expression Levels ofTEL, AML1, and the Fusion ProductsTEL-AML1 and AML1-TEL versus Drug Sensitivity and Clinical Outcome in $\mathrm{t}(12 ; 21)$-Positive Pediatric Acute Lymphoblastic Leukemia. Clin. Cancer Res. 2005;11:2974-80.

55. Mcwhirter JR, Neuteboom STC, Wancewicz EV, Monia BP, Downings JR, Murre C. Oncogenic homeodomain transcription factor E2A-Pbx1 activates a novel WNT gene in pre-B acute lymphoblastoid leukemia. Proc. Natl. Acad. Sci. 1999;96:11464-9. [CrossRef]
56. Rudolph C, Hegazy AN, Neuhoff NV, Steinemann D, Schröck E, Stripecke R, Klein C, Schlegelberger B. Cytogenetic characterization of a BCR-ABL transduced mouse cell line. Cancer Genetics and Cytogenetics 2005;161:51-6. [CrossRef]

57. Caslini C, Serna A, Rossi V, Introna M, Biondi A. Modulation of cell cycle by graded expression of MLLAF4 fusion oncoprotein. Leukemia 2004;18:1064-71. [CrossRef]

58. Martín-Subero JI, Odero MD, Hernandez R, Cigudosa JC, Agirre X, Saez B, Sanz-García E, Ardanaz MT, Novo FJ, Gascoyne RD, Calasanz MJ, Siebert R. Amplification of IGH/MYC fusion in clinically aggressive IGH/BCL2positive germinal center B-cell lymphomas. Genes Chromosomes Cancer 2005;43:414-23. [CrossRef]

59. Zalcberg IQ, Silva ML, Abdelhay E, Tabak DG, Ornellas MH, Simões FV, Pucheri W, Ribeiro R, Seuánez HN. Translocation 11;14 in three children with acute lymphoblastic leukemia of T-cell origin. Cancer Genet. Cytogenet. 1995;84:32-8. [CrossRef]

60. Paietta E, Racevskis J, Bennett JM, Wiernik PH. Differential expression of terminal transferase (TdT) in acute lymphocytic leukaemia expressing myeloid antigens and TdT positive acute myeloid leukaemia as compared to myeloid antigen negative acute lymphocytic leukaemia. Br. J. Haematol. 1993;84:416-22. [CrossRef]

61. Michiels JJ, Adriaansen HJ, Hagemeijer A, Hooijkaas H, van Dongen JJ, Abels J. TdT positive B-cell acute lymphoblastic leukaemia (B-ALL) without Burkitt characteristics. Br. J. Haematol. 1988;68:423-6. [CrossRef]

62. Slingerland JM, Minden MD, Benchimol S. Mutation of the p53 gene in human acute myelogenous leukemia. Blood 1951;77:1500-7.

63. Fenaux P, Jonveaux P, Quiquandon I, Lai JL, Pignon JM, Lefebvre MHL, Bauters F, Berger R, Kerckaert JP. P53 gene mutations in acute myeloid leukemia with $17 \mathrm{p}$ monosomy. Blood 1991;78:1652-7.

64. Zhao Z, Zuber J, Flores ED, Lintault L, Kogan SC, Shannon K, Lowe SW. p53 loss promotes acute myeloid leukemia by enabling aberrant self-renewal. Genes \& Development 2010;24:1389-402. [CrossRef]

65. Shikami M, Miwa H, Nishii K, Kyo T, Tanaka I, Shiku H, Kita K, Nitta M. Low p53 expression of acute myelocytic leukemia cells with $\mathrm{t}(8 ; 21)$ chromosome abnormality: Association with low p14ARF expression. Leukemia Research 2006;30:379-83. [CrossRef]

66. Trecca D, Longo L, Biondi A, Cro L, Calori R, Grignani F, Maiolo AT, Pelicci PG, Neri A. Analysis of p53 gene mutations in acute myeloid leukemia. American journal of hematology 1994;46:304-9. [CrossRef]

67. Melnick A, Licht JD. Deconstructing a disease: RARalpha, its fusion partners, and their roles in the pathogenesis of acute promyelocytic leukemia. Blood 1999;93:3167-215.

68. Tanner SM, Austin JL, Leone G, Rush LJ, Plass C, Heinonen K, Mrózek K, Sill H, Knuutila S, Kolitz JE, 
Archer KJ, Caligiuri MA, Bloomfield CD, de La Chapelle A. BAALC, the human member of a novel mammalian neuroectoderm gene lineage, is implicated in hematopoiesis and acute leukemia. Proc. Natl. Acad. Sci. 2001;98:13901-6. [CrossRef]

69. Rao VN, Modi WS, Drabkin HD, Patterson D, O'Brien SJ, Papas TS, Reddy ES. The human erg gene maps to chromosome 21 , band q22: relationship to the $8 ; 21$ translocation of acute myelogenous leukemia. Oncogene 1988;3:497-500.

70. Zhang Y, Strissel P, Strick R, Chen J, Nucifora G, Le Beau MM, Larson RA, Rowley JD. Genomic DNA breakpoints in AML1/RUNX1 and ETO cluster with topoisomerase II DNA cleavage and DNase I hypersensitive sites in $\mathrm{t}(8 ; 21)$ leukemia. Proc. Natl. Acad. Sci. 2002;99:3070-5. [CrossRef]

71. Im M, Lee JK, Lee DY, Hong YJ, Hong SI, Kang HJ, Chang YH. [Near-tetraploidy acute myeloid leukemia with RUNX1-RUNX1T1 rearrangement due to cryptic t(8;21)]. Korean J. Lab. Med. 2009;29:510-4. [CrossRef]

72. Jang JH, Yoo EH, Kim HJ, Kim DH, Jung CW, Kim SH. Acute myeloid leukemia with $\operatorname{del}(\mathrm{X})(\mathrm{p} 21)$ and cryptic RUNX1/RUNX1T1 from ins(8;21)(q22;q22q22) revealed by atypical FISH signals. Ann. Clin. Lab. Sci. 2010;40:80-4.

73. Schnittger S, Bacher U, Haferlach C, Kern W and Haferlach T. Rare CBFB-MYH11 fusion transcripts in AML with inv(16)/t $(16 ; 16)$ are associated with therapyrelated AML M4eo, atypical cytomorphology, atypical immunophenotype, atypical additional chromosomal rearrangements and low white blood cell count: a study on 162 patients. Leukemia 2007;21:725-31.

74. Tirado CA, Valdez F, Klesse L, Karandikar NJ, Uddin N, Arbini A, Fustino N, Collins R, Patel S, Smart RL, Garcia $\mathrm{R}$, Doolittle J, Chen W. Acute myeloid leukemia with inv(16) with CBFB-MYH11, 3'CBFB deletion, variant $\mathrm{t}(9 ; 22)$ with BCR-ABL1, and $\operatorname{del}(7)(\mathrm{q} 22 \mathrm{q} 32)$ in a pediatric patient: case report and literature review. Cancer Genet. Cytogenet. 2010;200:54-9. [CrossRef]

75. Usuki K, Nakatsu M, Kitazume K, Endo M, Osawa M, Iki $\mathrm{S}$, Arai M, Urabe A. CBFB/MYH11 fusion transcripts in a case of acute myelogenous leukemia (M1) with partial deletion of the long arm of chromosome 16. Intern. Med. 1996;35:327-30. [CrossRef]

76. Zent CS. Time to test CLL p53 function. Blood 2010;115:4154-5. [CrossRef]

77. Cordone I, Masi S, Mauro FR, Soddu S, Morsilli O, Valentini T, Vegna ML, Guglielmi C, Mancini F, Giuliacci S, Sacchi A, Mandelli F, Foa R. p53 Expression in B-Cell Chronic Lymphocytic Leukemia: A Marker of Disease Progression and Poor Prognosis. Blood 1998;91:4342-9.

78. Mackus WJM, Kater AP, Grummels A, Evers LM, Hooijbrink B, Kramer MHH, Castro JE, Kipps TJ, Lier RV, Oers MHJV, Eldering E. Chronic lymphocytic leukemia cells display p53-dependent drug-induced Puma upregulation. Leukemia 2005;19:427-34. [CrossRef]

79. Cartron G, Linassier C, Bremond JL, Desablens B, Georget MT, Fimbel B, Luthier F, Dutel JL, Lamagnere JP, Colombat P. CD5 negative B-cell chronic lympho- cytic leukemia: clinical and biological features of 42 cases. Leuk. Lymphoma 1998;31:209-16. [CrossRef]

80. Goller ME, Kneitz C, Mehringer C, Müller K, JelleyGibbs DM, Gosselin EJ, Wilhelm M, Tony HP. Regulation of CD23 isoforms on B-chronic lymphocytic leukemia. Leuk. Res. 2002;795-802. [CrossRef]

81. Fournier S, Delespesse G, Rubio M, Biron G, Sarfati M. CD23 antigen regulation and signaling in chronic lymphocytic leukemia. J. Clin. Invest. 1992;89:1312-21. [CrossRef]

82. Ghia P, Guida G, Stella S, Gottardi D, Geuna M, Strola G, Scielzo C, Caligaris-Cappio F. The pattern of CD38 expression defines a distinct subset of chronic lymphocytic leukemia (CLL) patients at risk of disease progression. Blood 2003;101:1262-9. [CrossRef]

83. Wiestner A, Rosenwald A, Barry TS, Wright G, Davis RE, Henrickson SE, Zhao H, Ibbotson RE, Orchard JA, Davis Z, Stetler-Stevenson M, Raffeld M, Arthur DC, Marti GE, Wilson WH, Hamblin TJ, Oscier DG, Staudt LM. ZAP-70 expression identifies a chronic lymphocytic leukemia subtype with unmutated immunoglobulin genes, inferior clinical outcome, and distinct gene expression profile. Blood 2003;101:4944-51. [CrossRef]

84. Lübbert M, Miller CW, Crawford L, Koeffler HP. p53 in Chronic Myelogenous Leukemia Study of Mechanisms of Differential Expression. J. Exp. Med. 1988;167:873-86. [CrossRef]

85. Tzankov A, Bourgau C, Kaiser A, Zimpfer A, Maurer R, Pileri SA, Went P, Dirnhofer S. Rare expression of T-cell markers in classical Hodgkin's lymphoma. Mod. Pathol. 2005; 18:1542-9.

86. Zukerberg LR, Collins AB, Ferry JA, Harris NL. Coexpression of CD15 and CD20 by Reed-Sternberg Cells in Hodgkin's Disease. Am. J. Pathol. 1991;139:475-83.

87. Tzankov A, Krugmann J, Fend F, Fischhofer M, Greil R, Dirnhofer S. Prognostic Significance of CD20 Expression in Classical Hodgkin Lymphoma: A Clinicopathological Study of 119 Cases. Clinical Cancer Research 2003;9:1381-6.

88. Tzardi M, Kouvidou C, Panayiotides I, Stefanaki K, Rontogianni D, Zois E, Koutsoubi K, Eliopoulos G, Delides G, and Kanavaros P. p53 protein expression in non-Hodgkin's lymphoma. Comparative study with the wild type p53 induced proteins mdm2 and p21/waf1. Clin. Mol. Pathol. 1996;49:M278-82. [CrossRef]

89. Piris MA, Villuendas R, Martinez JC, Sanchez-Beato M, Orradre JL, Mateo MS, Martinez P. p53 expression in non-Hodgkin's lymphomas: a marker of p53 inactivation? Leuk. Lymphoma 1995;17:35-42. [CrossRef]

90. Kaleem Z, McGuire MH, Caracioni AC, Leonard RL, Pathan MH, Lessmann EA, Chan WC. Composite B-Cell and T-Cell Non-Hodgkin Lymphoma of the Tibia. Am. J. Clin. Pathol. 2005;123:215-21. [CrossRef]

91. Lee JT, Innes DJ, Williams ME. Sequential bcl-2 and c-myc Oncogene Rearrangements Associated with the Clinical Transformation of Non-Hodgkin's Lymphoma. J. Clin. Invest. 1989;84:1454-9. [CrossRef]

92. Dierlamm J, Baens M, Wlodarska I, Ouzounova MS, 
Hernandez JM, Hossfeld DK, Peeters CDW, Hagemeijer A, Berghe HV, Marynen P. The Apoptosis Inhibitor Gene API2 and a Novel 18q Gene, MLT, Are Recurrently Rearranged in the $\mathrm{t}(11 ; 18)(\mathrm{q} 21 ; \mathrm{q} 21)$ Associated With Mucosa-Associated Lymphoid Tissue Lymphomas. Blood 1999;93:3601-9.

93. Streubel B, Lamprecht A, Dierlamm J, Cerroni L, Stolte M, Ott G, Raderer M, and Chott A. T(14;18)(q32;q21) involving IGH and MALT1 is a frequent chromosomal aberration in MALT lymphoma. Blood 2003;101:2335-9. [CrossRef]

94. Smith MR. Non-Hodgkin's lymphoma. Current Problems in Cancer 1996;20:6-77. [CrossRef]

95. Portier M, Molès JP, Mazars GR, Jeanteur P, Bataille R, Klein B, Theillet C. p53 and RAS gene mutations in multiple myeloma. Oncogene 1992;7:2539-43.

96. Neri A, Baldini L, Trecca D, Cro L, Polli E and Maiolo AT. p53 gene mutations in multiple myeloma are associated with advanced forms of malignancy. Blood 1993;81:128-35.

97. Greil R, Fasching B, Loidl P and Huber H. Expression of the c-myc proto-oncogene in multiple myeloma and chronic lymphocytic leukemia: an in situ analysis. Blood 1991;178:180-91.

98. Cobbold LC, Wilson LA, Sawicka K, King HA, Kondrashov AV, Spriggs KA, Bushell M, Willis AE. Upregulated c-myc expression in multiple myeloma by internal ribosome entry results from increased interactions with and expression of PTB-1 and YB-1. Oncogene 2010;29:2884-91. [CrossRef]

99. Pettersson M, Wiklund HJ, Larsson LG, Sundstrom C, Givol I, Tsujimoto Y and Nilsson K. Expression of the bcl-2 gene in human multiple myeloma cell lines and normal plasma cell. Blood 1992;179:495-50.

100. Pizzatti L, Sá LA, de Souza JM, Bisch PM, Abdelhay E. Altered protein profile in chronic myeloid leukemia chronic phase identified by a comparative proteomic study. Biochimica et Biophysica Acta

101. Barnidge DR, Tschumper RC, Jelinek DF, Muddiman DC, Kay NE. Protein expression profiling of CLL B cells using replicate off-line strong cation exchange chromatography and LC-MS/MS. Journal of Chromatography B 2005;819:33-9. [CrossRef]

102. Gez S, Crossett B, Christopherson RI. Differentially expressed cytosolic proteins in human leukemia and lymphoma cell lines correlate with lineages and functions. Biochimica et Biophysica Acta 2007;1774: 1173-83.

103. Zhang MZ, Sun ZC, Fu XR, Nan FF, Fan QX, Wu XA, Geng L, Ma W, Wang RL. Analysis of serum proteome profiles of non-Hodgkin lymphoma for biomarker identification. J. Proteomics 2009;72:952-9. [CrossRef]

104. Page MJ, Amess B, Townsend RR, Parekh R, Herath A, Brusten L, Zvelebil MJ, Stein RC, Waterfield MD, Davies SC, O'Hare MJ. Proteomic definition of normal human luminal and myoepithelial breast cells purified from reduction mammoplasties. Proc. Natl. Acad. Sci.
1999;96:12589-94. [CrossRef]

105. Allinen M, Beroukhim R, Cai L, Brennan C, LahtiDomenici J, Huang $\mathrm{H}$, Porter D, Hu M, Chin L, Richardson A, Schnitt S, Sellers WR, Polyak K. Molecular characterization of the tumor microenvironment in breast cancer. Cancer Cell 2004;6:17-32. [CrossRef]

106. Colavita I, Esposito N, Martinelli R, Catanzano F, Melo JV, Pane F, Ruoppolo M, Salvatore F. Gaining insights into the Bcr-Abl activity-independent mechanisms of resistance to imatinib mesylate in KCL22 cells: a comparative proteomic approach. Biochim. Biophys. Acta 2010;1804:1974-87.

107. He J, Shen D, Chung DU, Saxton RE, Whitelegge JP, Faull KF, Chang HR. Tumor proteomic profiling predicts the susceptibility of breast cancer to chemotherapy. Int. J. Oncol. 2009;35:683-92.

108. Rawstron AC, de Tute R, Jack AS, Hillmen P. Flow cytometric protein expression profiling as a systematic approach for developing disease-specific assays: identification of a chronic lymphocytic leukaemia-specific assay for use in rituximab-containing regimens. Leukemia 2006;20:2102-10. [CrossRef]

109. Ou K, Kesuma D, Ganesan K, Yu K, Soon SY, Lee SY, Goh XP, Hooi M, Chen W, Jikuya H, Ichikawa T, Kuyama H, Matsuo E, Nishimura O, Tan P. Quantitative profiling of drug-associated proteomic alterations by combined 2-nitrobenzenesulfenyl chloride (NBS) isotope labeling and 2DE/MS identification. J. Proteome Res. 2006;5:2194-206. [CrossRef]

110. Gavin AC, Aloy P, Grandi P, Krause R, Boesche M, Marzioch M, Rau C, Jensen LJ, Bastuck S, Dumpelfeld B, Edelmann A, Heurtier MA, Hoffman V, Hoefert C, Klein K, Hudak M, Michon AM, Schelder M, Schirle M, Remor M, Rudi T, Hooper S, Bauer A, Bouwmeester T, Casari G, Drewes G, Neubauer G, Rick JM, Kuster B, Bork P, Russell RB, Furga GS. Proteome survey reveals modularity of the yeast cell machinery. Nature 2006;440:631-6. [CrossRef]

111. Gavin AC, Bosche M, Krause R, Grandi P, Marzioch M, Bauer A, Schultz J, Rick JM, Michon AM, Cruciat CM, Remor M, Hofert C, Schelder M, Brajenovic M, Ruffner H, Merino A, Klein K, Hudak M, Dickson D, Rudi T, Gnau V, Bauch A, Bastuck S, Huhse B, Leutwein C, Heurtier MA, Copley RR, Edelmann A, Querfurth E, Rybin V, Drewes G, Raida M, Bouwmeester T, Bork P, Seraphin B, Kuster B, Neubauer G, Furga GS. Functional organization of the yeast proteome by systematic analysis of protein complexes. Nature 2002;415:141-7. [CrossRef]

112. Ho Y, Gruhler A, Heilbut A, Bader GD, Moore L, Adams SL, Millar A, Taylor P, Bennett K, Boutilier K, Yang L, Wolting C, Donaldson I, Schandorff S, Shewnarane J, Vo M, Taggart J, Goudreault M, Muskat B, Alfarano C, Dewar D, Lin Z, Michalickova K, Willems AR, Sassi H, Nielsen PA, Rasmussen KJ, Andersen JR, Johansen LE, Hansen LH, Jespersen H, Podtelejnikov A, Nielsen E, Crawford J, Poulsen V, Sorensen BD, Matthiesen J, 
Hendrickson RC, Gleeson F, Pawson T, Moran MF, Durocher D, Mann M, Hogue CW, Figeys D, Tyers M. Systematic identification of protein complexes in Saccharomyces cerevisiae by mass spectrometry. Nature 2002;415:180-3. [CrossRef]

113. Krogan NJ, Cagney G, Yu H, Zhong G, Guo X, Ignatchenko A, Li J, Pu S, Datta N, Tikuisis AP, Punna T, Peregrin-Alvarez JM, Shales M, Zhang X, Davey M, Robinson MD, Paccanaro A, Bray JE, Sheung A, Beattie B, Richards DP, Canadien V, Lalev A, Mena F, Wong P, Starostine A, Canete MM, Vlasblom J, Wu S, Orsi C, Collins SR, Chandran S, Haw R, Rilstone JJ, Gandi K, Thompson NJ, Musso G, St Onge P, Ghanny S, Lam MH, Butland G, Altaf-Ul AM, Kanaya S, Shilatifard A, O'Shea E, Weissman JS, Ingles CJ, Hughes TR, Parkinson J, Gerstein M, Wodak SJ, Emili A, Greenblatt JF. Global landscape of protein complexes in the yeast Saccharomyces cerevisiae. Nature 2006;440:637-43. [CrossRef]

114. Washburn MP, Wolters D, Yates JR. Large-scale analysis of the yeast proteome by multidimensional protein identification technology. Nature Biotechnology 2001;19:242-7. [CrossRef]

115. Ahram M. An introduction into proteomics and its clinical applications. Saudi Med. J. 2007;28:499-507.

116. MacBeath G, Schreiber SL. Printing proteins as microarrays for high-throughput function determination. Science 2000;289:1760-3.

117. Zhu H, Bilgin M, Bangham R, Hall D, Casamayor A, Bertone P, Lan N, Jansen R, Bidlingmaier S, Houfek T, Mitchell T, Miller P, Dean RA, Gerstein M, Snyder M. Global analysis of protein activities using proteome chips. Science 2001;293:2101-5. [CrossRef]

118. Zhu H, Klemic JF, Chang S, Bertone P, Casamayor A, Klemic KG, Smith D, Gerstein M, Reed MA, Snyder M. Analysis of yeast protein kinases using protein chips. Nature Genetics 2000;26:283-9. [CrossRef]

119. Bhat S, Patil A, Rai L, Kartha VB, Santhosh C. Protein profile analysis of cellular samples from the cervix for the objective diagnosis of cervical cancer using HPLCLIF. Journal of Chromatography B, 2010;878:3225-30. [CrossRef]

120. Vidyasagar MS, Kodali M, Balu PN, Baijal G, Vadhiraja BM, Bhat RA, Fernandes DJ, Krishna CM. Serum protein profile studies of cervical cancers in monitoring of tumor response to radiotherapy using HPLC-LIF: A pilot study. Medical Laser Application 2009;24:165-74. [CrossRef]
121. O'Farrell PH. High Resolution Two-Dimensional Electrophoresis of Proteins. The Journal of Biological Chemistry 1975;250:4007-21.

122. Bertone P, Snyder M. Advances in functional protein microarray technology. The FEBS Journal 2005;272:5400-11. [CrossRef]

123. Sreekumar A, Nyati MK, Varambally S, Barrette TR, Ghosh D, Lawrence TS, Chinnaiyan AM. Profiling of cancer cells using protein microarrays: discovery of novel radiation-regulated proteins. Cancer Research 2001;61:7585-93.

124. Kumar KK, Chowdary MVP, Mathew S, Rao L, Krishna CM, Kurien J. Protein profile study of breast-tissue homogenates by HPLC-LIF. Journal of BIOPHOTONICS 2009;2:313-21. [CrossRef]

125. Patil A, Prabhu V, Choudhari KS, Unnikrishnan VK, George SD, Ongole R, Pai KM, Shetty JK, Bhat S, Kartha VB, Chidangil S. Evaluation of high-performance liquid chromatography laser-induced fluorescence for serum protein profiling for early diagnosis of oral cancer. J Biomed Opt. 2010;15:067007. [CrossRef]

126. Venkatakrishna K, Kartha VB, Pai KM, Krishna CM, Ravikiran O, Kurien J, et al. HPLC-LIF for early detection of oral cancer. Curr. Sci. 2003;84:551-7.

127. Aebersold R, Mann M. Mass spectrometry-based proteomics. Nature 2003;422:198-207. [CrossRef]

128. Wolters DA, Washburn MP, Yates JR 3rd. An automated multidimensional protein identification technology for shotgun proteomics. Anal. Chem. 2001;73:5683-90. [CrossRef]

129. Issaq HJ, and Veenstra TD. Two-dimensional polyacrylamide gel electrophoresis (2D-PAGE): advances and perspectives. BioTechniques 25th Anniversary 2008;44:697-700.

130. Sydor JR, Nock S. Protein expression profiling arrays: tools for the multiplexed high-throughput analysis of proteins. Proteome Sci. 2003;1:3. [CrossRef]

131. Cho SY, Lee EY, Lee JS, Kim HY, Park JM, Kwon MS, Park YK, Lee HJ, Kang MJ, Kim JY, Yoo JS, Park SJ, Cho JW, Kim HS, Paik YK. Efficient prefractionation of low-abundance proteins in human plasma and construction of a two-dimensional map. Proteomics 2005;5:3386-96. [CrossRef]

132. Spisák S, Guttman A. Biomedical applications of protein microarrays. Curr. Med. Chem. 2009;16:2806-15. [CrossRef]

133. Spisak S, Tulassay Z, Molnar B, Guttman A. Protein microchips in biomedicine and biomarker discovery. Electrophoresis 2007;28:4261-73. [CrossRef] 